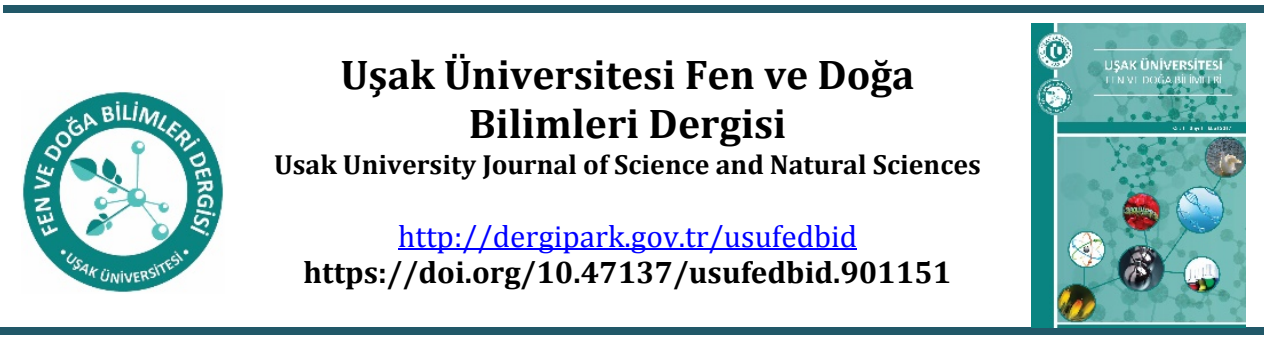

Araştırma makalesi

\title{
Bazı Çeltik Çeşitlerinde Toksik Düzeyde Demir İçerikli Tam Besin Çözeltisi Uygulamasının Taze Yapraklarda Glutatyon Redüktaz ve Askorbat Peroksidaz Aktiviteleri Üzerine Etkisi
}

\author{
Ahmet Korkmaz*, Güney Akınoğlu \\ Toprak Bilimi ve Bitki Besleme Bölümü, Ziraat Fakültesi, Ondokuz Mayıs Üniversitesi, Samsun, Türkiye \\ Geliş: 9 Arallk2021 Kabul: 21 Şubat2021 / Received: 9 December $2021 \quad$ Accepted: 21 February 2021
}

\begin{abstract}
The aim of this study is to determine the effect of toxic level iron containing complete nutrient solution application on glutathione reductase and ascorbate peroxidase activities in fresh leaves in some rice varieties. Iron in the form of iron sulphate is added to rice varieties grown in sand culture; Four different treatments were applied: I) 0, II) $45 \mu \mathrm{M}$ Fe (sufficient Fe), III) $3.50 \mathrm{mM}$ Fe (toxic Fe), IV) $3.50 \mathrm{mM}$ Fe (toxic $\mathrm{Fe}+$ sand media with bentonite) as four different treatments. Among the varieties grown at toxic iron level ( $3.50 \mathrm{mM} \mathrm{Fe})$, the variety with the highest ascorbate peroxidase enzyme activity value in fresh leaves is the Hamzadere variety, whereas the lowest variety is seen to be Edirne rice variety. Among the varieties grown at toxic iron level $(3.50 \mathrm{mM} \mathrm{Fe})$, the variety with the highest glutathione reductase enzyme activity value in fresh leaves is Hamzadere variety, whereas the lowest variety is seen to be Biga incisi rice variety.
\end{abstract}

Keywords: Rice variety, iron toxicity, glutathione reductase, ascorbate peroxidase

\section{Özet}

$\mathrm{Bu}$ çalışmanın amacı, bazı çeltik çeşitlerinde toksik düzeyde demir içerikli tam besin çözeltisi uygulamasının taze yapraklarda glutatyon redüktaz ve askorbat peroksidaz aktiviteleri üzerine etkisini belirlemektir. Kum kültüründe yetiştirilen çeltik çeşitlerine demir sülfat $\left(\mathrm{FeSO}_{4} .7 \mathrm{H}_{2} \mathrm{O}\right)$ formunda; I) 0 , II) $45 \mu \mathrm{M}$ Fe (yeterli Fe), III) $3.50 \mathrm{mM}$ Fe (toksik Fe), IV) $3.50 \mathrm{mM} \mathrm{Fe}$ (toksik Fe + bentonitli ortam) şeklinde olmak üzere dört farklı muamele uygulanmıştır. Toksik demir düzeyinde (3.50 mM Fe) yetiştirilen çeşitler arasında taze yaprakta askorbat peroksidaz enzim aktivite değeri en yüksek çeşidin Ronaldo çeşidi olduğu; buna karşın, en düşük çeşidin ise Edirne çeltik çeşidi olduğu görülmektedir. Toksik demir düzeyinde yetiştirilen çeşitlerden glutatyon redüktaz aktivitesi en yüksek çeltik çeşidinin Osmancık-97 çeşidi olduğu; buna karşın, en düşük çeşidin ise Biga İncisi olduğu tespit edilmiştir.

Anahtar Kelimeler: Çeltik çeşidi, demir toksisitesi, glutatyon redüktaz, askorbat peroksidaz

\footnotetext{
*Corresponding author:

E-mail: akorkmaz5155@gmail.com (ORCID ID: 0000-0001-5595-0618)
}

(C)2021 Usak University all rights reserved. 


\section{Giriş}

Bitkilerin stres faktörlerine karşı olan toleransları farklıdır. Bunda bitkinin türü, stres faktörü, strese maruz kalma süresi ve strese maruz kalan doku veya organın yapısı etkilidir. Bitkilerin bu ağır metallere karşı hangi tepkiler verdiğini ve hangi savunma mekanizmaları geliştirdiğini belirlemek oldukça önemlidir [1].

Abiyotik stres şartları altında bitkilerde reaktif oksijen türleri (ROS) olarak adlandırılan oldukça toksik ve reaktif moleküller olușmaktadır. Bu moleküller protein, lipid karbohidrat ve DNA'nın yapısını bozarak oksidatif stresin oluşmasına neden olmaktadır. $\mathrm{Bu}$ hasarın önlenmesine yönelik olarak bitkiler de antioksidant savunma sistemlerine sahiptir. Bu antioksidant sistemler enzimatik (süperoksit dismutaz, SOD; katalaz, CAT; askorbat peroksidaz, APX; glutatyon redüktaz, GR vb.) ve enzimatik olmayan (fenolik bileşikler, alkoloid, askorbik asit, glutatyon vb.) olmak üzere ikiye ayrılır [2].

Ağır metaller membran lipidlerinin de dahil olduğu biyomoleküllere hasar vererek oksidatif stresin oluşmasına neden olan hidrojen peroksit $\left(\mathrm{H}_{2} \mathrm{O}_{2}\right)$ gibi reaktif oksijen türlerinin (ROS) oluşumuna neden olmaktadır [3].

Demir minerali bakımından noksan olan çeltik bitkisinin köklerinde azalmış askorbat peroksidaz seviyelerinin olduğu rapor edilmiştir [4]. Askorbat peroksidaz bir hemoprotein olduğundan Fe eksikliği, askorbat peroksidaz aktivitesinde bir azalmaya neden olur $[5,6,7]$. Demir içeren peroksidaz, katalaz ve süperoksit dismutaz gibi antioksidatif enzim aktivitelerinin, bitkinin iç Fe durumu ile ilişsili olduğu bildirilmiştir [8]. Bitkide demir toksisitesine karşı koruma stratejileri; süperoksit dismutaz, katalaz ve askorbat peroksidaz gibi antioksidan enzimlerin etkilerini içeren enzimatik mekanizmaları içerebilir $[9,10]$. Enzimatik olmayan mekanizmalar, indirgenmiş glutatyon, a-tokoferol, askorbik asit ve karotenoidler gibi organik bileşikler yoluyla oksijen reaktif türlerini nötraliz edebilir [11].

Becana vd, (1998), serbest $\mathrm{Fe}^{+2}$ iyonunun, bitki hücreleri içerisinde Fenton reaksiyonu yoluyla tekli oksijen, süperoksit radikalleri $\left(\mathrm{O}^{-2}\right)$, hidrojen peroksit $\left(\mathrm{H}_{2} \mathrm{O}_{2}\right)$ ve hidroksil radikali (OH:) dahil olmak üzere reaktif oksijen türlerinin (ROS) oluşumunu hızlandırdığını bildirmişlerdir [5]. ROS'un, toksik olup; lipidlere, proteinlere ve nükleik asitlere verilen zararla doğrudan ilișkili olduğu araștırıcılar tarafından bildirilmiştir.

Tiryakioğlu vd, (2006), bitkilerin ROS'u uzaklaştırmak ve zararlı etkilerini azaltmak için birkaç koruyucu enzimatik ve enzimatik olmayan mekanizma geliştirdiğini rapor etmişlerdir [12]. CAT, peroksidazlar, askorbat peroksidaz, SOD ve glutatyon redüktaz gibi ROS temizleme enzimleri ile glutatyon, askorbat ve karotenoidler gibi birtakım antioksidanların bitkilerde ROS detoksifikasyonunu gerçekleștirdiği yine aynı araștırıcılar tarafından bildirilmiştir.

$\mathrm{Bu}$ çalışmanın amacı, bazı çeltik çeşitlerinde toksik düzeyde demir içerikli tam besin çözeltisi uygulamasının taze yapraklarda glutatyon redüktaz ve askorbat peroksidaz aktiviteleri üzerine etkisini belirlemektir.

\section{Materyal ve Yöntem}

Kum kültüründe sera şartlarında yetiștirilen çeltik çeşitleri Karadeniz Tarımsal Araştırma Enstitüsü'nden temin edilmiştir. Bu çeşitler: Biga incisi, Osmancık-97, Hamzadere, Ronaldo ve Edirne çeltik çeşitleridir. 


\subsection{Deneme}

Çeltik tohumları \% 5.0'lık (v/v) sodyum hipoklorit çözeltisi içerisinde 15 dakika bekletilerek, tohumların sterilizasyonu sağlanmıştır. Daha sonra çeltik tohumları deiyonize su ile yıkanıp nemli bez torbalarda çimlendirildi. Çimlenen tohumlar, içerisinde perlit bulunan $40 \times 25 \times 5 \mathrm{~cm}$ boyutundaki beyaz plastik küvetlere aktarılarak 10 gün içinde çeltik fideleri haline gelmesi sağlandı. Çeltik fideleri $1 \mathrm{~kg}$ kuvars kumu dolu plastik saksılara $(12 \times 12 \mathrm{~cm})$ her saksıda 10 bitki olacak șekilde dikilmiştir.

Çeltik çeşitlerine demir sülfat $\left(\mathrm{FeSO}_{4} \cdot 7 \mathrm{H}_{2} \mathrm{O}\right.$ ) formunda; I) 0, II) $45 \mu \mathrm{M}$ Fe (yeterli Fe), III) $3.50 \mathrm{mM} \mathrm{Fe}$ (toksik Fe), IV) $3.50 \mathrm{mM} \mathrm{Fe}$ (toksik Fe+ bentonitli ortam) şeklinde olmak üzere dört farklı muamele uygulanmıștır.

Denemede saksılardaki kum yüzeyinden itibaren $3 \mathrm{~cm}$ su katmanı olacak şekilde besin çözeltisi 5 farklı çeltik çeşidine eşit hacimlerde ilave edilmiştir. Bitki besin çözeltisinin pH'sı seyreltik $\mathrm{HCl}$ ya da $\mathrm{KOH}$ çözeltisi kullanılarak 5.5'e ayarlanmıştır. Deneme 50 gün sürmüștür.

Denemede Zhang ve ark. (1998) tarafından bildirilen ve demir içermeyen aşağıdaki konsantrasyonlarda mutlak gerekli besin maddelerini içeren bitki besin çözeltisi kullanılmıștır [13].

$500 \mu \mathrm{M} \mathrm{NH}_{4} \mathrm{NO}_{3} ; 60 \mu \mathrm{M} \mathrm{NH}_{4} \mathrm{H}_{2} \mathrm{PO}_{4} ; 230 \mu \mathrm{M} \mathrm{K}_{2} \mathrm{SO}_{4} ; 210 \mu \mathrm{M} \mathrm{CaCl}_{2} ; 160 \mu \mathrm{M} \mathrm{MgSO}_{4} \cdot 7 \mathrm{H}_{2} \mathrm{O}$; $2.5 \mu \mathrm{M} \mathrm{MnCl}_{2} ; 0.75 \mu \mathrm{M}\left(\mathrm{NH}_{4}\right) 6 \mathrm{Mo}_{7} \mathrm{O}_{24} ; 3.2 \mu \mathrm{M} \mathrm{H}_{3} \mathrm{BO}_{3} ; 0.1 \mu \mathrm{M} \mathrm{CuSO}_{4} ; 2.0 \mu \mathrm{M} \mathrm{ZnSO}_{4} \cdot 7 \mathrm{H}_{2} \mathrm{O}$

\subsection{Bitkinin taze yaprağında bazı enzim aktivitelerinin belirlenmesi}

Taze yapraklarda glutatyon redüktaz (GR) ve askorbat peroksidaz (APX) aktivitesini belirlemek amacıyla; demir noksanlığı, yeterli demir düzeyinde ve bentonitli ve bentonit ilavesiz toksik demir düzeylerinde yetiştirilen çeltik çeşitlerinden ayrı ayrı besin çözeltisi uygulamasından 3 gün sonra enzim analizleri için bitkilerden taze yaprak örnekleri alınmıştır. Hasat edilen çeltik bitkisi yaprakları sıvı azotla dondurularak, biyokimyasal analizlere kadar $-86{ }^{\circ} \mathrm{C}^{\prime}$ de saklanmıştır. Bazı enzim analizleri için bitki ekstraktının hazırlanmasında ise aşağıdaki proses gerçekleşmiştir:

GR ve APX enzimlerinin ekstraksiyonu için yaklaşık $0.5 \mathrm{~g}$ taze yaprak örneği sıvı azot içerisinde porselen havan yardımıyla ezilip toz haline getirildikten sonra, \% $1.0(\mathrm{w} / \mathrm{v})$ polivinil polipirolidon (PVPP) ve $1.0 \mathrm{mM}$ EDTA içeren 0,05 M sodyum fosfat tamponuyla (pH 7.8) içerisinde homojenize edilmiştir. Homojenize edilen örnekler 20 dakika süresince $20.000 \mathrm{x}$ g'de santrifüj edildikten sonra elde edilen süpernatantlar, enzim analizlerinde kullanılmıştır. Enzim aktivitelerinin belirleneceği örnekler, ölçüm yapılıncaya kadar $\pm 4{ }^{\circ} \mathrm{C}$ sıcaklıkta tutulmuştur.

Taze yaprak örneklerinde Askorbat peroksidaz (APX) aktivitesi, Amako vd, (1994) tarafından bildirilen metoda göre yapılmıștır [14]. Glutatyon redüktaz (GR) aktivite tayini, NADPH'ın oksidasyonunun $340 \mathrm{~nm}$ 'de izlenmesi esasına dayanmaktadır. Aktivite ölçümü, $50 \mathrm{mM}$ potasyum fosfat ( $\mathrm{pH}=7.0$ ) tamponu, $2.0 \mathrm{mM} \mathrm{Na}{ }_{2}$ EDTA, $0.15 \mathrm{mM} \mathrm{NADPH}$, $0.5 \mathrm{mM}$ GSSG ve $100 \mathrm{~mL}$ enzim ekstraktı içeren karışımın 1 mL'sinin 3 dakikada 340 nm'deki değişimi ölçülerek yapılmıştır (Jiang vd, 2002) [15].

Numune ölçümleri OMÜ Ziraat Fakültesi Tarımsal Biyoteknoloji Bölümü laboratuvarında Analytic Jena 40 model UV-Spektrofotometre cihazı kullanılarak yapılmıştır. Her aktivite tayininde ölçümler 3 kez tekrarlanmıştır. 


\section{3. İstatistiksel Analizler}

Faktöriyel deneme deseni 5 x 4 olup, varyans analizi SPSS 17.0 paket programı ile yapılmıştır.

\section{Bulgular ve Tartışma}

\subsection{Toksik düzeyde demir içeren tam besin çözeltisi uygulamasının çeltik çeşitlerinde taze yaprakta glutatyon redüktaz aktivitesi üzerine etkisi}

Çeltik çeşitlerinde toksik düzeyde demir içerikli tam besin çözeltisi uygulamasının taze yaprakta glutatyon redüktaz aktivitesine etkisine ilişkin varyans analiz sonuçları Tablo 1 'de verilmiştir.

Tablo 1. Çeltik çeşitlerinde toksik düzeyde demir içerikli tam besin çözeltisi uygulamasının taze yaprakta glutatyon redüktaz aktivitesine etkisine ilişkin varyans analiz sonuçları

\begin{tabular}{lcccccccc}
\hline & \multicolumn{9}{c}{ Varyasyon kaynakları } \\
\hline \multirow{2}{*}{ Özellik } & $\begin{array}{c}\text { Demir sülfat } \\
\text { dozu }\end{array}$ & \multicolumn{2}{c}{ Çeşit } & \multicolumn{2}{c}{$\begin{array}{c}\text { Demir sülfat dozu } \times \text { çeşit } \\
\text { interaksiyonu }\end{array}$} & Hata \\
\cline { 2 - 10 } & SD & KO & SD & KO & SD & KO & SD & KO \\
\hline Glutatyon redüktaz & 3 & $0.001^{*}$ & 4 & 0.001 & 12 & $9.737 \mathrm{E}-5^{*}$ & 40 & $4.938 \mathrm{E}-5$ \\
\hline
\end{tabular}

${ }^{* *} \mathrm{p}<0.01 ;{ }^{*} \mathrm{p}<0.05$; SD: Serbestlik derecesi; KO: Kareler ortalaması

Çeltik çeşitlerinde toksik düzeyde demir içerikli tam besin çözeltisi uygulamasının taze yaprakta glutatyon redüktaz aktivitesine etkisine ilişkin değerler Tablo 2'de verilmiştir.

Tablo 2. Çeltik çeşitlerinde toksik düzeyde demir içerikli tam besin çözeltisi uygulamasının taze yaprakta glutatyon redüktaz aktivitesine etkisi

\begin{tabular}{|c|c|c|c|c|c|}
\hline \multirow{2}{*}{ Çeltik çeşidi } & \multicolumn{5}{|c|}{$\begin{array}{c}\text { Glutatyon redüktaz } \\
\text { Spesifik aktivite (EU / mg) }\end{array}$} \\
\hline & $\begin{array}{c}\text { Fe 0 } \\
\text { (Kontrol) }\end{array}$ & $45 \mu \mathrm{M} \mathrm{Fe}$ & $3.50 \mathrm{mM}$ Fe & $\begin{array}{c}3.50 \mathrm{mM} \mathrm{Fe}+ \\
\% 10 \\
\text { Bentonit }\end{array}$ & Ortalama \\
\hline Biga incisi & 0.024 bcde & $0.032 \mathrm{abcd}$ & $0.027 \mathrm{bcde}$ & $0.032 \mathrm{abcd}$ & 0.0289 \\
\hline Osmancık-97 & $0.015 \mathrm{e}$ & $0.029 \mathrm{bcd}$ & $0.044 \mathrm{a}$ & $0.032 \mathrm{abcd}$ & 0.0301 \\
\hline Hamzadere & 0.025 bcde & $0.029 \mathrm{bcd}$ & $0.029 \mathrm{bcd}$ & $0.019 \mathrm{de}$ & 0.0252 \\
\hline Ronaldo & $0.029 \mathrm{bcd}$ & $0.035 \mathrm{abc}$ & 0.031abcd & $0.038 \mathrm{ab}$ & 0.0333 \\
\hline Edirne & 0.024 bcde & $0.026 \mathrm{bcde}$ & $0.029 \mathrm{bcd}$ & $0.026 \mathrm{bcde}$ & 0.0262 \\
\hline Ortalama & $0.0233 B$ & $0.0304 \mathrm{~A}$ & $0.0319 A$ & $0.0294 \mathrm{~A}$ & \\
\hline
\end{tabular}

*Aynı harflerle gösterilen ortalamalar arasında \% 5 düzeyinde fark yoktur

Tablo 1 ve 2'nin incelenmesinden anlaşılacağı üzere demir dozunun, demir dozu×çeşit interaksiyonunun taze yaprakta glutatyon redüktaz aktivitesine etkisi $\mathrm{p}<0.05$ seviyesinde istatistiksel olarak önemli bulunmuştur. Buna karşın, taze yaprakta glutatyon redüktaz aktivitesine çeşidin etkisi istatistiksel olarak önemsiz bulunmuştur. Yeterli demir düzeyi, toksik demir düzeyi ve bentonit ilaveli kum ortamındaki toksik demir düzeyi uygulamaları, kontrole kıyasla çeltik bitkisinin taze yapraklarında glutatyon redüktaz 
aktivitesini önemli derecede arttırmıştır. Çeltik çeşitleri taze yapraklarda glutatyon redüktaz aktivite değerleri bakımından birbirlerine benzer bulunmuștur (Tablo 2).

Toksik konsantrasyonda demir uygulaması sonucu, Osmancık-97 ve Edirne çeltik çeşitlerinde glutatyon redüktaz aktivitesi artış göstermiş; buna karşın, diğer çeşitlerde azalma eğilimi göstermiştir.

Değişik konsantrasyonlarda demir içeren demir sülfatlı besin çözeltileri ile yetiştirilen çeşitlerin taze yapraklarında belirlenen glutatyon redüktaz aktivite değerleri farklılık göstermiştir (Şekil 1).

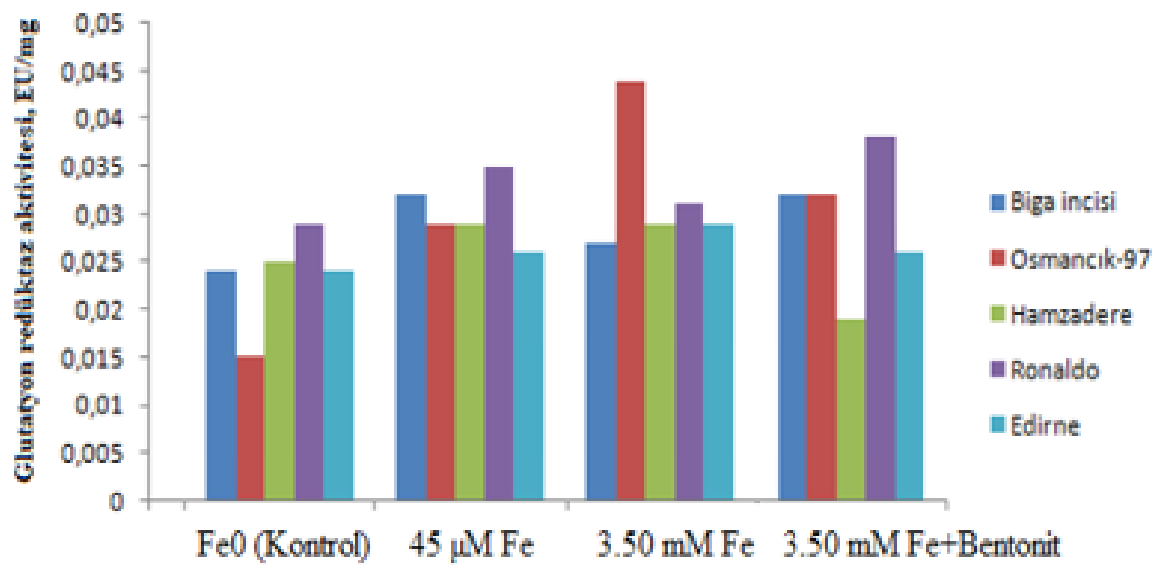

Şekil 1. Çeltik çeşitlerinde toksik düzeyde demir içerikli tam besin çözeltisi uygulamasının taze yaprakta glutatyon redüktaz enzim aktivitesine etkisi

Şekil 1'in incelenmesinden anlaşılacağı üzere demir noksanlığı şartlarında (Fe0) yetiştirilen çeltik çeşitleri arasında taze yaprakta glutatyon redüktaz enzim aktivite değeri en yüksek çeşidin Ronaldo çeşidi olduğu; buna karşın, en düşük çeşidin ise Osmancık-97 çeltik çeşidi olduğu görülmektedir. Yeterli demir düzeyinde (45 $\mu \mathrm{M} \mathrm{Fe}$ ) yetiştirilen çeşitler arasında taze yaprakta glutatyon redüktaz enzim aktivite değeri en yüksek çeşidin Ronaldo çeşidi olduğu; buna karşın, en düşük çeşidin ise Edirne çeltik çeşidi olduğu görülmektedir. Toksik demir düzeyinde (3.50 mM Fe) yetiştirilen çeşitler arasında taze yaprakta glutatyon redüktaz enzim aktivite değeri en yüksek çeşidin Osmancık-97 çeşidi olduğu; buna karşın, en düşük çeşidin ise Biga incisi çeltik çeşidi olduğu görülmektedir. Bentonit ilaveli kum ortamında toksik demir düzeyinde $(3.50 \mathrm{mM}$ $\mathrm{Fe}+\% 10$ Bentonit) yetiştirilen çeşitler arasında taze yaprakta glutatyon redüktaz enzim aktivite değeri en yüksek çeşidin Ronaldo çeşidi olduğu; buna karşın, en düşük çeşidin ise Hamzadere çeltik çeşidi olduğu görülmektedir. Kum ortamına toksik düzeyde demir sülfatlı besin çözeltisi uygulaması sonucu Osmancık-97 çeltik çeşidinde taze yaprakta glutatyon redüktaz aktivitesi kontrole göre \% 193.3; yeterli demir düzeyine göre ise \% 51.7 oranında artış göstermiştir. Toksik düzeyde demir içeren demir sülfatlı besin çözeltisi uygulamasının, yeterli demir düzeyine kıyasla taze yaprakta glutatyon redüktaz aktivitesine etkisi Hamzadere çeltik çeşidinde önemsiz bulunmuştur. Ek olarak, toksik düzeyde demir sülfatlı besin çözeltisi uygulaması, yeterli demir düzeyine göre taze yaprakta glutatyon redüktaz aktivitesini Biga incisi ve Ronaldo çeltik çeşitlerinde azaltmış; fakat Edirne ve Osmancık-97 çeltik çeşitlerinde ise arttırmıştır.

Toksik düzeyde demir sülfatlı besin çözeltisi uygulanan çeşitler taze yaprakta glutatyon redüktaz aktivite değerleri bakımından yüksek değerden düşük değere doğru sırasıyla; 
Osmanclk-97 >Ronaldo > Edirne $>$ Hamzadere > Biga incisi șeklinde sıralanmıștır. Buna göre toksik demir düzeyinde yetiștirilen çeșitlerden glutatyon redüktaz aktivitesi en yüksek çeltik çeşidinin Osmancık 97 çeşidi olduğu; buna karşın, en düşük çeşidin ise Biga İncisi olduğu tespit edilmiştir.

Demir noksanlığı șartlarında (Fe0) ise çeşitler taze yaprakta glutatyon redüktaz aktivite değerleri bakımından büyükten küçüğe doğru sırasıyla; Ronaldo > Hamzadere > Edirne > Biga incisi > Osmancık-97 șeklinde sıralanmıștır. Yeterli demir düzeyinde ise taze yaprakta glutatyon redüktaz aktivite değerleri bakımından çeşitler büyükten küçüğe doğru sırasıyla; Ronaldo > Biga incisi > Osmancık-97 > Hamzadere > Edirne șeklinde sıralanmıştır. Bentonit ilaveli (\% 10) kum ortamına toksik düzeyde demir sülfatlı besin çözeltisi uygulaması ile yetiștirilen çeșitler taze yaprakta glutatyon redüktaz aktivite değerleri bakımından büyükten küçüğe doğru sırasıyla; Ronaldo > Biga incisi > Osmancık-97 > Edirne > Hamzadere șeklinde sıralanmıștır.

Glutatyon redüktaz; glutatyon peroksidazın ve glutatyon S-transferazın katalizlediği reaksiyonlar esnasında oluşan okside glutatyonu redükte glutatyona dönüştürmek sureti ile dolaylı olarak antioksidan etki gösteren bir enzimdir [16].

\subsection{Toksik düzeyde demir içeren tam besin çözeltisi uygulamasının çeltik çeşitlerinde taze yaprakta askorbat peroksidaz aktivitesi üzerine etkisi}

Çeltik çeşitlerinde toksik düzeyde demir içerikli tam besin çözeltisi uygulamasının taze yaprakta askorbat peroksidaz aktivitesine etkisine ilişkin varyans analiz sonuçları Tablo 1 'de verilmiştir.

Tablo 3. Çeltik çeşitlerinde toksik düzeyde demir içerikli tam besin çözeltisi uygulamasının taze yaprakta glutatyon redüktaz aktivitesine etkisine ilişkin varyans analiz sonuçları

\begin{tabular}{lcccccccc}
\hline & \multicolumn{7}{c}{ Varyasyon kaynakları } \\
\hline \multirow{2}{*}{ Özellik } & Demir sülfat dozu & & \multicolumn{2}{c}{ Çeşit } & \multicolumn{2}{c}{$\begin{array}{c}\text { Demir sülfat dozu } \times \text { çeșit } \\
\text { interaksiyonu }\end{array}$} & Hata \\
& SD & KO & SD & KO & SD & KO & SD & KO \\
\hline $\begin{array}{l}\text { Askorbat } \\
\text { peroksidaz }\end{array}$ & 3 & $0.021^{* *}$ & 4 & $0.003^{* *}$ & 12 & $0.033^{* *}$ & 40 & $9.935 \mathrm{E}-5$ \\
\hline
\end{tabular}

${ }^{* *} \mathrm{p}<0.01 ;{ }^{*} \mathrm{p}<0.05$; SD: Serbestlik derecesi; KO: Kareler ortalaması

Çeltik çeşitlerinde toksik düzeyde demir içerikli tam besin çözeltisi uygulamasının taze yaprakta askorbat peroksidaz aktivitesine etkisine ilişkin değerler Tablo 4'te verilmiştir. 
Tablo 4. Çeltik çeşitlerinde toksik düzeyde demir içerikli tam besin çözeltisi uygulamasının taze yaprakta askorbat peroksidaz aktivitesine etkisi

\begin{tabular}{|c|c|c|c|c|c|}
\hline \multirow[b]{2}{*}{ Çeltik çeşidi } & \multicolumn{5}{|c|}{$\begin{array}{c}\text { Askorbat peroksidaz } \\
\text { spesifik aktivite (EU / mg) }\end{array}$} \\
\hline & $\begin{array}{c}\text { Fe 0 } \\
\text { (Kontrol) }\end{array}$ & $45 \mu \mathrm{M} F e$ & $3.50 \mathrm{mM} \mathrm{Fe}$ & $\begin{array}{c}3.50 \mathrm{mMFe}+ \\
\% 10 \\
\text { Bentonit }\end{array}$ & Ortalama \\
\hline Biga incisi & $0.262 \mathrm{j}$ & $0.388 \mathrm{f}$ & $0.424 \mathrm{de}$ & $0.478 \mathrm{bc}$ & $0.3883 \mathrm{AB}$ \\
\hline Osmancik-97 & $0.331 \mathrm{~h}$ & $0.424 \mathrm{de}$ & $0.361 \mathrm{~g}$ & $0.466 c$ & $0.3960 \mathrm{~A}$ \\
\hline Hamzadere & $0.418 \mathrm{de}$ & $0.364 \mathrm{~g}$ & $0.432 \mathrm{~d}$ & $0.212 \mathrm{k}$ & $0.3568 \mathrm{C}$ \\
\hline Ronaldo & $0.336 \mathrm{~h}$ & $0.494 \mathrm{~b}$ & $0.525 a$ & 0.187 l & $0.3861 \mathrm{~B}$ \\
\hline Edirne & $0.344 \mathrm{~h}$ & $0.412 \mathrm{e}$ & $0.301 \mathrm{i}$ & $0.466 \mathrm{c}$ & $0.3803 \mathrm{~B}$ \\
\hline Ortalama & $0.3385 \mathrm{D}$ & $0.4170 \mathrm{~A}$ & $0.4090 \mathrm{~B}$ & $0.3613 \mathrm{C}$ & \\
\hline
\end{tabular}

*Aynı harflerle gösterilen ortalamalar arasında \% 5 düzeyinde fark yoktur

Tablo 3 ve 4'ün incelenmesinden anlaşılacağı üzere demir dozunun, çeşidin, demir dozu×çeșit interaksiyonunun taze yaprakta askorbat peroksidaz aktivitesine etkisi $\mathrm{p}<0.01$ seviyesinde istatistiksel olarak önemli bulunmuștur. Yeterli ve toksik düzeyde demir sülfat içeren besin çözeltisi uygulamaları (bentonitsiz ve bentonit ilaveli kum ortamında) kontrole kıyasla, taze yaprakta askorbat peroksidaz aktivitesini önemli derecede arttırmıștır. Genel ortalamalar dikkate alındı ğında, taze yaprakta askorbat peroksidaz aktivite değerleri bakımından çeltik çeșitler büyükten küçüğe doğru sırasıyla; Osmancık-97 > Biga incisi > Ronaldo > Edirne > Hamzadere şeklinde sıralanmıștır (Tablo 4).

Toksik konsantrasyonda demir uygulaması sonucu, Biga İncisi, Hamzadere ve Ronaldo çeltik çeşitlerinde askorbat peroksidaz aktivitesi artış göstermiş; buna karşın, diğer çeșitlerde azalma eğilimi göstermiștir.

Değișik konsantrasyonlarda demir içeren demir sülfatlı besin çözeltileri ile yetiștirilen çeltik çeșitlerinin taze yapraklarında belirlenen askorbat peroksidaz aktivite değerlerinin farklı olduğu görülmüştür (Şekil 2).

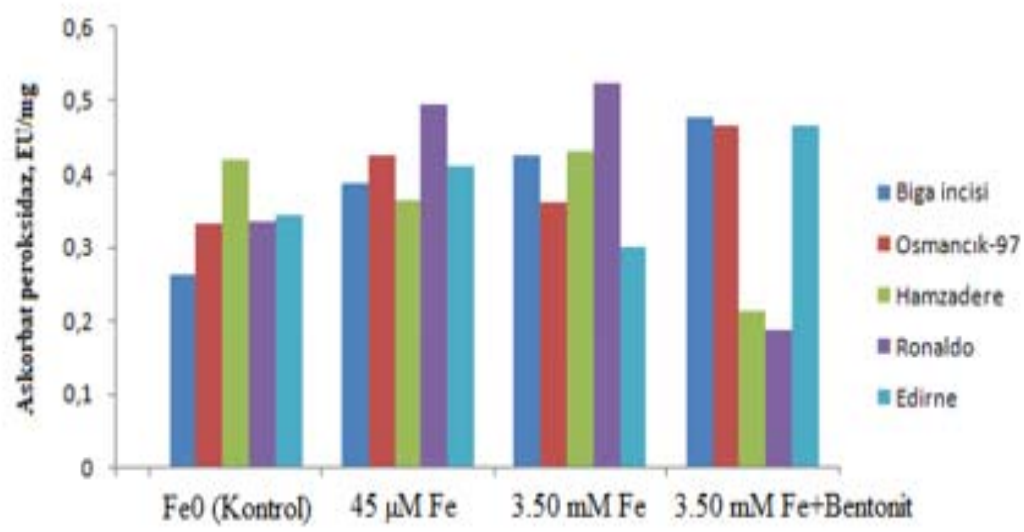

Şekil 2. Çeltik çeşitlerinde toksik düzeyde demir içerikli tam besin çözeltisi uygulamasının taze yaprakta askorbat peroksidaz enzim aktivitesine etkisi 
Şekil 2'nin incelenmesinden anlaşılacağı üzere demir noksanlığı (Fe0) șartlarında yetiştirilen çeltik çeșitleri arasında taze yaprakta askorbat peroksidaz enzim aktivite değeri en yüksek çeșidin Hamzadere çeșidi olduğu; buna karșın, en düșük çeșidin ise Biga incisi çeltik çeșidi olduğu görülmektedir. Yeterli demir düzeyinde $(45 \mu \mathrm{M} \mathrm{Fe})$ yetiștirilen çeșitler arasında taze yaprakta askorbat peroksidaz enzim aktivite değeri en yüksek çeșidin Ronaldo çeșidi olduğu; buna karșın, en düșük çeșidin ise Hamzadere çeltik çeșidi olduğu görülmektedir. Toksik demir düzeyinde $(3.50 \mathrm{mM} \mathrm{Fe})$ yetiștirilen çeșitler arasında taze yaprakta askorbat peroksidaz enzim aktivite değeri en yüksek çeșidin Ronaldo çeșidi olduğu; buna karșın, en düșük çeșidin ise Edirne çeltik çeșidi olduğu görülmektedir. Bentonit ilaveli kum ortamında toksik demir düzeyinde $(3.50 \mathrm{mM} \mathrm{Fe}+\%$ 10 Bentonit) yetiștirilen çeșitler arasında taze yaprakta askorbat peroksidaz enzim aktivite değeri en yüksek çeșidin Biga incisi çeșidi olduğu; buna karșın, en düșük çeșidin ise Ronaldo çeltik çeșidi olduğu görülmektedir. Askorbat peroksidaz (APX), substrat olarak askorbatı kullanarak $\mathrm{H}_{2} \mathrm{O}_{2}$ gibi peroksitleri detoksifiye eden enzimdir (Raven, 2000).

Biga incisi çeltik çeşidine toksik düzeyde demir (3.50 mM Fe) içeren tam besin çözeltisi uygulaması, yeterli düzeyde demir $(45 \mu \mathrm{M} \mathrm{Fe})$ içeren tam besin çözeltisi uygulamasına kıyasla taze yaprakta peroksidaz ve glutatyon redüktaz enzim aktivitelerini azaltmış; fakat katalaz ve askorbat peroksidaz enzim aktivitelerini arttırmıștır.

Osmanclk-97 çeltik çeșidine toksik düzeyde demir (3.50 mM Fe) içeren tam besin çözeltisi uygulaması, yeterli düzeyde demir $(45 \mu \mathrm{M} \mathrm{Fe})$ içeren tam besin çözeltisi uygulamasina klyasla taze yaprakta peroksidaz, katalaz, ve askorbat peroksidaz enzim aktivitelerini azaltmış; fakat glutatyon redüktaz enzim aktivitesini arttırmıştır.

Hamzadere çeltik çeşidine toksik düzeyde demir (3.50 mM Fe) içeren tam besin çözeltisi uygulaması, yeterli düzeyde demir ( $45 \mu \mathrm{M} \mathrm{Fe})$ içeren tam besin çözeltisi uygulamasına kıyasla taze yaprakta peroksidaz enzim aktivitesini azaltmış; fakat katalaz ve askorbat peroksidaz enzim aktivitelerini arttırmış, glutatyon redüktaz aktivitesinin seviyesini ise etkilememiştir.

Ronaldo çeltik çeşidine toksik düzeyde demir ( $3.50 \mathrm{mM} \mathrm{Fe}$ ) içeren besin çözeltisi uygulaması, yeterli düzeyde demir $(45 \mu \mathrm{M} \mathrm{Fe})$ içeren tam besin çözeltisi uygulamasına kıyasla taze yaprakta peroksidaz, katalaz, glutatyon redüktaz enzim aktivitelerini azaltmış; fakat askorbat peroksidaz aktivitesini arttırmıștır.

Edirne çeltik çeşidine toksik düzeyde demir (3.50 mM Fe) içeren tam besin çözeltisi uygulaması, yeterli düzeyde demir $(45 \mu \mathrm{M}$ Fe) içeren tam besin çözeltisi uygulamasına kıyasla taze yaprakta peroksidaz, katalaz, askorbat peroksidaz enzim aktivitelerini azaltmış; fakat glutatyon redüktaz enzim aktivitesini arttırmıștır.

Mineral eksiklikleri, antioksidan enzimlerin aktivitesini etkileyen ana stres faktörleri arasındadır (Chou vd, 2011). Özellikle demir (Fe) minerali, hem az hem de toksik seviyelerde bulunduğunda oksidatif strese yol açabilir. Aslında, Fe birçok antioksidan enzimin bir kofaktörüdür ve aynı zamanda "Fenton reaksiyonu" yoluyla reaktif oksijen türleri (ROS) üretebilir [8]. Bitkiler, ROS üreten zincir reaksiyonlarının yayılmasını durduran bir dizi antioksidatif yanıt yoluyla değişen Fe homeostazından kaynaklanan oksidatif hasarı azaltmak için farklı mekanizmalar geliştirmiştir. $\mathrm{Bu}$ durumda, $\mathrm{O}_{2}$ 'yi $\mathrm{H}_{2} \mathrm{O}_{2}$ 'ye dönüștüren süperoksit dismutaz (SOD), ROS'a karşı ilk savunma hattını oluşturur [18]. Bu antioksidan tepkinin, bitkileri aşırı UV ışığı, tuzluluk, kuraklık, ağır metaller ve besin yoksunluğu dahil olmak üzere çeșitli çevresel stresler altında oksidatif hasara karşı korumak için kritik olduğu düşünülmektedir [19]. Aynı zamanda, $\mathrm{H}_{2} \mathrm{O}_{2}$ detoksifikasyonu spesifik olmayan peroksidaz (POD) ve katalaz (CAT) enzimleri tarafindan kontrol edilebilir [20]. 


\section{Sonuçlar}

Toksik demir düzeyinde (3.50 mM Fe) yetiştirilen çeşitler arasında taze yaprakta askorbat peroksidaz enzim aktivite değeri en yüksek çeşidin Ronaldo çeşidi olduğu; buna karşın, en düşük çeşidin ise Edirne çeltik çeşidi olduğu görülmektedir. Toksik konsantrasyonda demir uygulaması sonucu, Biga İncisi, Hamzadere ve Ronaldo çeltik çeşitlerinde askorbat peroksidaz aktivitesi artış göstermiş; buna karşın, diğer çeşitlerde azalma eğilimi göstermiştir.

Toksik demir düzeyinde yetiştirilen çeşitlerden glutatyon redüktaz aktivitesi en yüksek çeltik çeşidinin Osmancık 97 çeşidi olduğu; buna karşın, en düşük çeşidin ise Biga İncisi olduğu tespit edilmiştir. Toksik konsantrasyonda demir uygulaması sonucu, Osmancık-97 ve Edirne çeltik çeşitlerinde glutatyon redüktaz aktivitesi artış göstermiş; buna karşın, diğer çeşitlerde azalma eğilimi göstermiştir.

\section{Teșekkür}

Bu çalışma, Güney Akınoğlu'nun doktora tezinden hazırlanmıștır.

Denemede materyal olarak kullanılan çeltik çeşitlerinin teminini sağlayan; T.C. Tarım ve Orman Bakanlığı Karadeniz Tarımsal Araştırma Enstitüsü Müdürlüğüne teşekkür ederiz. Ayrıca, bu çalışmanın laboratuvar analizleri aşamasındaki katkılarından dolayı Ondokuz Mayıs Üniversitesi Ziraat Fakültesi Tarımsal Biyoteknoloji Bölümü asistanlarına çok teşekkür ederiz.

\section{Çıkar Çatışması Beyanı}

Makale yazarları aralarında herhangi bir çıkar çatışması olmadığını beyan ederler.

\section{Kaynaklar}

1. Koç E, Üstün AS, Arıcı YK. Biber (Capsicum annuum L.) fidelerinde farklı çinko konsantrasyonlarının total protein, hidrojen peroksit içeriği ve peroksidaz aktivitesi üzerine etkisi. Artvin Coruh Üniversitesi Orman Fakültesi Dergisi, 2012;13(2):205-212.

2. Gill SS, Tuteja N. Reactive oxygen species and antioxidant machinery in abiotic stress tolerance in crop plants. Plant Physiology and Biochemistry, 2010;48:909930.

3. Burzynski M, Klobus G. Changes of photosynthetic parameters in cucumber leaves under $\mathrm{Cu}, \mathrm{Cd}$ and $\mathrm{Pb}$ stress. Photosynth 2004;42(4): 505-510.

4. Chen L, Ding C, Zhao X, Xu J, Mohammad AA, Wang S, Ding Y. Differential regulation of proteins in rice (Oryza sativa L.) under iron deficiency. Plant Cell Reports, 2015;34:83-96.

5. Becana M, Moran JF, Iturbe-Ormaetxe, I, Escuredo, PR. Iron-dependent oxygen free radical generation in plants subjected to environmental stress: toxicity and antioxidant protection. Plant Soil, 1998;201(1):137-147. doi: 10.1023/A:1004375732137 
6. Iturbe-Ormaetxe I, Moran JF, Arrese-Igor C, Gogorcena Y, Klucas YC, Becana M. Activated oxygen and antioxidant defences in iron-deficient pea plants. Plant Cell and Environment, 1995;18:421-429.

7. Sun B, Jing Y, Chen K, Song L, Chen F, Zhang L. Protective effect of nitric oxide on iron deficiency-induced oxidative stress in maize (Zea mays). Journal of Plant Physiology, 2007;164(5):536-43. doi: 10.1016/j.jplph.2006.02.011.

8. Daşgan HY, Öztürk L, Abak K, Çakmak I. Activities of iron-containing enzymes in leaves of two tomato genotypes differing in their resistance to $\mathrm{Fe}$ chlorosis. Journal of Plant Nutrition, 2003;26:1997-2007.

9. Majerus V, Bertin P, Swenden V, Fortemps A, Lobréaux S, Lutts S. Organdependent responses of the African rice to short-term iron toxicity: ferritin regulation and antioxidative responses. Biology Plant, 2007b;51:303-312.

10. Saikia T, Baruah, KK. Iron Toxicity Tolerance in Rice (Oryza sativa) and Its Association with Anti-Oxidative Enzyme Activity. Journal of Crop Science, 2012;3(3):90-94.

11. Smirnoff N. Ascorbate, tocopherol and carotenoids: metabolism, pathway engineering and functions. In: Smirnoff N (Ed) Antioxidants and reactive oxygen species in plants. 1st Edn. Oxford: Blackwell Publishing Ltd, 2005. p. 53-86.

12. Tiryakioglu M, Eker S, Özkutlu F, Husted S, Çakmak I. Antioxidant defense system and cadmium uptake in barley genotypes differing in cadmium tolerance. Journal of Trace Elements in Medicine and Biology, 2006;20:181-189. doi:10.1016/j.jtemb.2005.12.004

13. Zhang $X$, Zhang F, Mao D. Effect of Fe plaque outside roots on nutrient uptake by rice (Oryza sativa L.): zinc uptake. Plant and Soil, 1998;202:33-39.

14. Amako K, Chen G-X, Asada K. Separate assays specific for ascorbate peroxidase and guaiacol peroxidase and for the chloroplastic and cytosolicisozymes of ascorbate peroxidase in plants. Plant Cell Physiology, 1994;35:497-504.

15. Jiang $M$, Zhang J. Water stress-induced abscisic acid accumulation triggers the increased generation of reactive oxygen species and up-regulates the activities of antioxidant enzymes in maize leaves. Journal of Experimental Botany, 2002;53(379):2401-2410.

16. Peter H. Protoctor and Edward S.Reynolds, Free radicals and disaase in man, Psiolo Che-Phys-Med, 1984;16:175-195.

17. Chou T-S, Chao Y-Y, Huang W-D, Hong C-Y. Effect of magnesium deficiency on antioxidant status and cadmium toxicity in rice seedlings. Journal of Plant Physiology, 2011;168(10):1021-1030.

18. Mittler R. Oxidative stress, antioxidants and stress tolerance. Trends in Plant Science, 2002;7(9): 405-410.

19. Molassiotis A, Sotiropoulos T, Tanou G, Diamantidis G. Boron-induced oxidative damage and antioxidant and nucleolytic responses in shoot tips culture of the apple rootstock EM 9 (Malus domestica Borkh). Environmental and Experimental Botany, 2006a;56(1):54-62.

20. Corpas FJ, Palma JM, Sandalio LM, López-Huertas E, MC, Romero-Puertas MC, Barroso JB, Del Río LA. Purification of catalase from pea leaf peroxisomes: identification of five different isoforms. Free Radical Research, 1999;31:235-241. 